\title{
Diagnoza psychiki na podstawie marzenia sennego
}

\section{Początki psychoterapeutycznej analizy i interpretacji snów - psychoanaliza Freuda}

\subsection{Naukowe podstawy psychoanalizy}

Sigmund Freud to twórca psychologicznej analizy i interpretacji marzeń sennych oraz prekursor współczesnej psychoterapii. Ten austriacki neurolog, opracowując teorię leczenia nerwic, doszedł do wniosku, że ich źródło leży w nieświadomości. Marzenie senne zaś uznał za „królewską drogę” do niej (Freud 1952).

Psychoanaliza opierała się na doktrynach dziewiętnastowiecznej nauki (Hobson, McCarley 1977). Freud zakładał między innymi, że organizm jest złożonym systemem pobierającym ze świata energię dzięki pożywieniu i oddającym ją z powrotem do środowiska za pośrednictwem wykonywanych akcji. Ponadto przyjmował za współczesną mu neurofizjologią izomorfizm ciała oraz umysłu. Zakładał, że umysł i ciało to jedna substancja przybierająca różne formy. Dodatkowo wykorzystał w konstruowaniu swojej teorii zasady zachowania energii. Założył na jej podstawie, że energia nie znika, a jedynie zmienia formę. Ze względu na opisane założenia koncepcja psychiki człowieka Freuda jest jednocześnie mechanistyczna oraz deterministyczna (Hall, Lindzey, Campbell 2010). Stąd znacznym nieporozumieniem jest ciągłe spieranie się w artykułach naukowych z klasyczną, freudowską psychoanalizą, gdyż już od wielu lat jej podstawy są przedawnione.

$\mathrm{Z}$ podstaw teoretycznych, które przyjął Freud, wynikły następujące konsekwencje dla psychoanalizy:

1. założenie, że energia, którą posługuje się ciało, i energia poruszająca umysł to ten sam rodzaj energii pochodzący z pożywienia;

2. przyjęcie, że energia, która została „zaanektowana” przez psychikę, musi znaleźć ujście (zgodnie z zasadą zachowania energii nie może po prostu zniknąć).

Powrócę do tych wątków później.

\subsection{Model strukturalny ludzkiego umysłu a sny}

Współcześni badacze spostrzegli, że opisy psychiki ludzkiej według Freuda można podzielić na pięć różnych metateorii (Drat-Ruszczak 2000). Jedna z nich zakłada podział psychiki na trzy struktury: id, ego oraz superego. 
Id („to”) jest rezerwuarem energii psychicznej. Jak wspomniałem wyżej, w nim energia organizmu zostaje przekształcona $w$ energię psychiczną. $W$ id powstają dwa podstawowe rodzaje energii psychicznej, które dążą do wyładowania: libido (energia twórcza, afiliacyjna, seksualna) oraz destrudo (energia zniszczenia, separacji i alienacji) (Drozdowski, Kokoszka 1993). Zadaniem id jest realizacja potrzeb organizmu w ich najbardziej pierwotnej formie. Jeśli jest to niemożliwe w fizycznym świecie, id dokonuje wyobrażeniowego zaspokojenia potrzeb przez halucynowane ich przeżycie (Hall, Lindzey, Campbell 2010). Na przykład głodująca osoba, która nie ma dostępu do pożywienia, marzy o tym, że je (Freud 2004). W ten sposób „zaspokaja” potrzebę w jedyny możliwy dla niej sposób (Hall, Lindzey, Campbell 2010). Id jest w całości nieuświadomione.

Superego („nad-ja”) zawiera w sobie normy, które jednostka nabyła w procesie socjalizacji. Jest bezrefleksyjne i działa automatycznie. Część superego człowiek może sobie uświadomić.

Ego (,ja”) to organizacja sprawująca kontrolę nad całą psychiką człowieka. W części jest uświadomione, a w części nie. Jego zadaniem jest godzenie potrzeb id z wymaganiami rzeczywistości oraz standardami superego. Ważne, by nie łączyć ego z samoświadomością oraz tożsamością. Tymi konstruktami zajmuje się bardziej współczesna psychoanaliza, jak psychologia self (por. Hall, Lindzey, Campbell 2010)

Z powyższego opisu widać, że marzenie senne rodzi się z id - jak każdy akt psychiczny. W jego powstawaniu jednak doniosłą rolę odgrywa również cenzura związana z superego (Freud 2004).

\subsection{Praca marzenia sennego}

Marzenie senne w koncepcji Freuda to strażnik spokojnego snu. Potrzeby id na jawie są trzymane w ryzach przez ego oraz superego. Podczas snu te dwie „wyższe” instancje słabną i id ma dużo większy wpływ (Freud 2004). Zdaniem Freuda - domaga się podczas snu zaspokojenia swoich potrzeb i marzenie senne to wspomniane wyżej halucynowane zaspokojenie potrzeby (Freud 1952, 2004). Czemu jednak często to zaspokojenie wygląda w tak nieoczywisty sposób? Freud uważa, że marzenie senne w wielu wypadkach służy zaspokojeniu nieakceptowanych społecznie impulsów - seksualnych lub agresywnych. Sen musi ich spełnienie ukryć przed śpiącym, by silne emocje związane z nieakceptowanym pragnieniem nie przerwały spokojnego wypoczynku. Dzieje się to za pośrednictwem pracy snu, w której Freud wyróżnia kilka mechanizmów:

- zagęszczenie - służy skompresowaniu wielu wątków albo obiektów w jeden (Vedfelt 1998). Na przykład zdarza się, że osoba śniąca widzi we śnie nieznajomego chłopczyka, co do którego czuje, że jest jednocześnie jej wujkiem i ojcem. Zagęszczenie - prócz swojej funkcji ekonomicznej - jednocześnie ukrywa niektóre znaczenia przez ich pomieszanie;

- dramatyzacja - polega na nadaniu snu dramatycznej formy, „ubraniu” pragnień, impulsów i myśli w formę wydarzeń; 
- przesunięcie - to zmiana akcentu we śnie. Służy odsunięciu nacisku snu od nieakceptowalnych społecznie treści tak, by pozostały jeszcze mniej czytelne. Jeśli - zgodnie z koncepcją Freuda - osoba śniłaby o seksie, to nie dość, że przez działanie cenzury seks zostałby zamieniony na jakąś inną rytmiczną czynność, na przykład wchodzenie po drabinie (por. Freud 2004), to jeszcze najpewniej akcent z wchodzenia po drabinie zostałby przesunięty na coś innego - osoba mogłaby dostrzegać lecącego w jej stronę smoka i sama wspinaczka nie byłaby tak ważna;

- uspójnienie - zdaniem Freuda to mechanizm, który nie występuje we wszystkich snach. Jego zadanie polega na nadaniu tematu całemu snu i połączenie jego scen tak, by tworzyły jedną „sensowną” całość.

Cała praca marzenia sennego przekształca treść ukrytą (prawdziwą treść procesów psychiki człowieka, gdy śpi) w treść jawną - niekoniecznie logiczną i sensowną, ale za to akceptowalną społecznie wersję, która nie sprawi, że osoba śniąca wybudzi się.

\subsection{Podsumowanie i wnioski}

Reasumując - Freud uważał, że marzenie senne to strażnik spokojnego snu człowieka napastowanego ciągłymi pragnieniami nienasyconego id. Swoją funkcję spełnia przez halucynowane zaspokajanie tych pragnień oraz - jeśli są nieakceptowalne społecznie - przez ich ukrycie przed śniącym za pośrednictwem pracy snu.

Teoria marzenia sennego Freuda ma obecnie wartość głównie historyczną. Powstała w innych warunkach społeczno-psychologicznych oraz na podłożu przedawnionych teorii przyrodniczych. Jej wartość w określaniu rzeczywistych właściwości psychiki człowieka jest niewielka i nieudowodniona (Hall, Lindzey, Campbell 2010).

\section{Dalszy rozwój psychoanalitycznych koncepcji marzenia sennego}

\subsection{Psychologia analityczna Junga}

Jedną z najbardziej rozbudowanych teorii interpretacji marzeń sennych stworzył Carl Gustav Jung, uczeń Freuda. Ten austriacki psychiatra był jednym z pierwszych odstępców od Freuda. Odłam stworzony przez Junga nosi nazwę psychologii analitycznej (Hall, Lindzey, Campbell 2010).

\subsubsection{Struktura psychiki według Junga}

Carl Gustav Jung uważał, że w psychice człowieka są zawarte biologiczne elementy, wspólne dla wszystkich ludzi, które wynikają z historii gatunku (Dudek 2007; Jung 1995). Nazwał je archetypami. Poza nimi istnieje też część umysłu charakterystyczna dla danej jednostki, tej jednak psycholog poświęcał mniej uwagi. 
Archetypy, które najczęściej można zaobserwować w codziennym funkcjonowaniu ludzi albo właśnie w snach, to Cień, Persona, Anima i Animus.

Persona to zdaniem Junga wynikający z ewolucji mechanizm, który powstał ze względu na to, że człowiek nigdy nie może „być sobą" w społeczeństwie (Jung 1981). Według twórcy psychologii analitycznej przymus wielokrotnego zakładania przez ludzi „masek” przez całe pokolenia sprawił, że w drodze ewolucji stały się one elementem naszego naturalnego wyposażenia. W codziennym życiu Persona objawia się w zachowaniu i myślach, które towarzyszą nam w obecności innych, zaś byłyby nam obce w sytuacji samotności. W snach Persona może występować symbolicznie jako maska, przebranie, „bycie kimś innym” (nie sobą) itp.

Cień to zwierzęce dążenia i nieakceptowane społecznie treści psychiczne, z którymi człowiek się nie utożsamia. Ma często charakter mroczny, agresywny czy wręcz demoniczny i tak się przejawia w snach - jako zagrażające śniącemu osoby, zwierzęta czy stworzenia nadprzyrodzone (Dudek 2007; Vedfelt 1998). W zachowaniu objawia się jako niechciane i represjonowane dążenia czy myśli, których człowiek wstydzi się tuż po ich pomyśleniu.

Animus/Anima to archetypy płciowe. Zdaniem Junga zdrowy mężczyzna utożsamia się ze swoim Animusem, a jego Anima pozostaje nieuświadomiona. Zdrowa kobieta zaś utożsamia się z Animą przy nieuświadomionym Animusie. $\mathrm{Na}$ jawie archetypy te przejawiają się odpowiednio zachowaniami typowymi dla mężczyzn (zdecydowaniem, agresją, ekspansywnością) oraz kobiet (spolegliwością, ugodowością, opiekuńczością). Należy podkreślić, że Jung tworzył swoją teorię na podstawie różnych dzieł kultury, filozofii oraz tekstów powiązanych z magią i alchemią (Hall, Lindzey, Campbell 2010). Nie musi ona tym samym pozostawać w zgodzie z odkryciami psychologii społecznej i socjologii (szczególnie nurtu gender) wskazujących na negatywne rezultaty stereotypizowania (por. Wojciszke 2012).

Innym ważnym archetypem - choć nieczęsto zauważalnym w snach i zachowaniu - jest Jaźń. To archetyp pełni człowieczeństwa, do której zdaniem Junga dąży każda dusza ludzka. Dążenie to realizuje przez proces indywiduacji (Dudek 2007; Jung 1999; Vedfelt 1998). Indywiduacja rozpoczyna się na dobre około pięćdziesiątego roku życia. Wtedy też zaczynają się pojawiać sny archetypowe obrazujące drogę człowieka do osiągnięcia pełni funkcjonowania.

\subsubsection{Zasady interpretacji snów}

Jung skodyfikował zasady interpretacji snów w nurcie psychologii analitycznej (Vedfelt 1998). Na sen należy spoglądać jak na dramat grecki. We śnie można wyróżnić:

1. ekspozycję, czyli określenie czasu, miejsca oraz osób biorących udział we śnie;

2. komplikację, czyli rozwinięcie akcji;

3. klimaks - punkt kulminacyjny, w którym następuje pozytywne rozwiązanie lub katastrofa;

4. lysis - zakończenie snu i rozwiązanie jego akcji. 
Ekspozycja i komplikacja obrazują problem będący tematem snu, klimaks oraz lysis wskazują możliwości przebrnięcia przez opisywany problem oraz sugerują sposoby jego rozwiązania.

Marzenie senne według Junga może posiadać aspekt redukcyjny oraz aspekt prospektywny. Pierwszy z nich odnosi się do przeszłości i interpretacja przez jego pryzmat służy określeniu, jakie wydarzenia z przeszłości zdeterminowały sen. Aspekt prospektywny, który znacznie bardziej interesował samego twórcę psychologii analitycznej, jest skierowany w przyszłość. Wskazuje na obecne siły działające w człowieku, które dążą do zmiany jego sytuacji.

Do skutecznej interpretacji snu Jung zalecał analizę jego kontekstu. Stosował w tym celu metodę skojarzeń z danym elementem marzenia lub amplifikacji jego składnika.

Metoda skojarzeń polega na prostym podawaniu tego, co w umyśle danej osoby łączyło się z elementem snu będącym punktem zainteresowania analityka. Natomiast metoda amplifikacji polega na tworzeniu kontekstu symbolicznego dla interesującego elementu snu - poszukiwaniu symboli tak związanych z własnymi przeżyciami, z życiem kultury danej osoby, jak i z kontekstem ogólnoludzkim archetypowym (por. Vedfelt 1998).

Ważnym składnikiem dobrej interpretacji marzenia sennego było też ustalenie, czy osoby obecne we śnie to elementy osobowości śniącego (plan subiektywny) czy zobrazowanie rzeczywistych osób z jego otoczenia (plan obiektywny).

Interpretację obiektywną z reguły stosuje się wtedy, gdy postać we śnie jest kimś ważnym dla śniącego. Podobnie sprawa ma się z osobami, które niekoniecznie są ważne, ale relacja z nimi obecnie rodzi żywe emocje. Tę samą zasadę stosuje się najczęściej do postaci widzianych we śnie ostro i szczegółowo.

Gdy postać ze snu jest osobą niezbyt ważną lub w ogóle niezwiązaną ze śpiącym, używa się interpretacji subiektywnej. Aplikuje się ją również, kiedy bohater ten jest zniekształcony lub zmieniony w inny sposób. Te akurat zasady są sformułowane ogólnikowo i można je łamać, jeśli pozostałe elementy kontekstu wskazują na inny rodzaj interpretacji.

Ostatecznym sprawdzeniem interpretacji snu jest jego weryfikacja. Jung proponuje kilka jej metod. Przede wszystkim sny należy interpretować seriami, nie osobno. Jeśli kolejne sny w niedługim czasie potwierdzają interpretację, oznacza to jej słuszność. Jeśli nie, należy stworzyć nową ramę, która połączy wszystkie marzenia senne serii (Dudek 2007; Vedfelt 1998).

Trafność interpretacji potwierdza również - jak określa to Ole Vedfelt - poczucie „aha” u śniącego, kiedy słyszy interpretację. Śniący wewnętrznie czuje, że jest ona słuszna.

Kolejnym sposobem weryfikacji jest to, że zaproponowana przez terapeutę interpretacja prowadzi do określonych rezultatów w życiu śniącego. 


\subsubsection{Podsumowanie i wnioski}

Jung stworzył kompletnie inną szkołę terapii niż jego nauczyciel Freud, która wykorzystywała marzenia senne w odmienny sposób. Skupiała się na interpretacjach dotyczących przyszłości śniącego, na rozwoju jego duszy oraz badaniu tego, co nieświadomość chciała zakomunikować śniącemu w jego marzeniu.

Teoria stworzona przez Junga nadal jest chętnie wykorzystywana przez neojungistów. Obrazowe, intuicyjnie opisane archetypy widać nie tylko w snach, ale także w szeroko pojętym zachowaniu. Można więc na podstawie jungowskiej diagnozy snów próbować wnioskować o właściwościach psychicznych śniącego.

Jungiści nie uznają jednak akademickich metod badania słuszności swoich teorii. Są one również skonstruowane tak, że wymykają się podejściom eksperymentalnym (Dudek 2007; Hall, Lindzey, Campbell 2010). Wywodzące się z psychologii indywidualnej nurty neojungowskie interpretacji marzeń sennych mają więc wartość głównie terapeutyczną, a nie diagnostyczną.

\subsection{Psychologia indywidualna}

Kolejnym uczniem, który opuścił Freuda w celu stworzenia własnej szkoły terapii, był Alfred Adler (Hall, Lindzey, Campbell 2010). Wykreował on koncepcję psychologii indywidualnej, która skupiała się wokół specyficznego dla jednostki stylu życia będącego jej sposobem na ucieczkę od nieuniknionego poczucia niższości. Wbrew swojemu mentorowi - jak i wielu jego uczniom - Adler uznał świadomość za centrum osobowości człowieka.

\subsubsection{Interpretacja snów $w$ psychologii indywidualnej}

Według Adlera marzenie senne to kontynuacja życia na jawie i że widać w nim tę samą niepowtarzalną osobowość człowieka, która nadaje piętno jego codziennemu życiu. Sugerował jednocześnie, że osoby śniące próbują w snach rozwiązywać problemy, z którymi nie poradziły sobie na jawie (Doweiko 1982; Lombardi, Elcock 1997; Vedfelt 1998).

Sen także - zdaniem Adlera - obrazuje i wspomaga w przeciwstawieniu się wymaganiom życia w społeczeństwie elementy stylu życia danej osoby: jej zindywidualizowaną logikę i zindywidualizowany rozum (Doweiko 1982; Lombardi, Elcock 1997).

Interpretacja snów w psychologii indywidualnej opiera się na wspólnym ze śniącym nadawaniu znaczenia symbolom obecnym we śnie (Lombardi, Elcock 1997).

\section{Współczesne podstawy nauki o marzeniach sennych}

Psychoanaliza wyrasta z dziewiętnastowiecznej nauki. Koncepcje terapii i marzeń sennych omówione w części drugiej opierają się natomiast bezpośrednio na 
psychoanalizie. Odkrycia, które opiszę w tej części, leżą u podłoża współczesnych koncepcji marzeń sennych.

\subsection{Chronobiologia}

Już w 1932 roku Eugene Aserinsky i Nathaniel Kleitman odkryli, że sen to zjawisko fazowe (Borbély 1990; Zimbardo 1999; Zimbardo, Johnson, McCann 2012). W marzeniu sennym można wyróżnić dwie fazy: REM (Rapid Eye Movement) oraz NREM (Non Rapid Eye Movement). W pierwszej z nich oczy osób śpiących poruszają się bardzo szybko, a ciało jest unieruchomione. Druga faza to odpoczynek ciała i powolne ruchy gałek ocznych.

Zgodnie ze współczesną chronopsychologią sen jest rytmem mezogennym. Rytmy endogenne są związane z biologicznym wyposażeniem organizmu. Dopasowują się jedynie do środowiska zewnętrznego, ale nie są przez nie warunkowane. Rytmy egzogenne są warunkowane i wyznaczane przez środowisko zewnętrzne, są efektem uczenia się. Rytm snu-czuwania posiada jakości obu tych rytmów (Ciarkowska 2015). Z jednej strony jest nieodzowny dla przetrwania ludzkiego organizmu, należy do biologicznego wyposażenia człowieka. W ten sposób jest rytmem endogennym. Z drugiej zaś jest w znacznym stopniu warunkowany życiem społecznym, wykonywanym zawodem czy nawet wolicjonalną zmianą nawyków, tym samym zbliżając się do rytmów egzogennych. Współcześnie uważa się, że bardziej pierwotny jest cykl fazy REM.

\subsection{Neurologia}

W 1977 roku J. Allan Hobson oraz Robert McCarley opisali hipotezę aktywacji-syntezy będącą współczesną bazą dla teorii marzeń sennych. Według niej w fazie REM dopływ bodźców zewnętrznych jest ograniczony. Mózg jednak pozostaje pod wpływem chaotycznej stymulacji pochodzącej z pnia mózgu. Jak wspomniałem powyżej, ciało osoby w fazie REM jest unieruchomione, jednak mięśnie są wciąż pobudzane przez połączenia nerwowe. Stymulowane są również nerwy wzrokowe. Opisana aktywacja nerwowo-mięśniowa zostaje połączona ze śladami pamięciowymi, które najbardziej do niej pasują. W ten sposób powstaje marzenie senne.

\subsection{Podsumowanie}

Najnowsze teorie marzeń sennych opierają się na odkryciach współczesnej nauki. Jedną z podstaw dla nich jest regularność snu wyznaczana mezogennym rytmem snu-czuwania. Drugim neurologiczne podstawy wskazujące na to, że bazą dla snu jest chaotyczna impulsacja z pnia mózgu pobudzająca mózg, mięśnie oraz nerwy wzrokowe.

Hobson i McCarley nie podają w swojej pracy ramy interpretacyjnej snów (Hobson, McCarley 1977). Nie wykluczają jednak ich sensu odkrytego przez inne teorie. 


\section{Poznawcze rozumienie marzenia sennego}

Interpretacja marzenia sennego - choć kojarzona głównie z psychoanalizą i pokrewnymi jej szkołami psychoterapii - była również obecna przy narodzinach terapii poznawczej (Rosner 2004). Aaron Beck, jeden z ojców tego podejścia starał się zaszczepić tę technikę diagnozy także i na jego gruncie. Ze względu jednak na sojusze terapeutów poznawczych z terapeutami behawioralnymi, którzy nie byli zwolennikami interpretacji marzeń sennych, oraz na żmudnośći problematyczność badania samych marzeń sennych, zarzucił swoje prace.

Beck uważał, że marzenie senne to biopsja procesów poznawczych osoby śniącej ukazująca w sposób wyolbrzymiony względem codziennego funkcjonowania różnorodne błędy, które są nieodzowne dla systemu poznawczego człowieka. Błędy, których (w dużym uproszczeniu) eliminacją lub redukcją zajmuje się właśnie terapia poznawcza oraz poznawczo-behawioralna (Padesky, Greenberger 2004).

Współcześnie tematem interpretacji marzeń sennych w paradygmacie poznawczym zajął się Harold Doweiko. Opierając się na teorii Alfreda Adlera, stwierdził, że zindywidualizowany rozum oraz zindywidualizowana logika opisane przez twórcę psychologii indywidualnej to nic innego jak "zestaw poznawczy" osób śniących, czyli w uproszczeniu - podobnie do spojrzenia Aarona Becka - to, co odpowiada za wszelkie błędy poznawcze również na jawie (Doweiko 1982). Dodał do tego współczesną neurologię (por. 3.2.) i uznał, że zestaw poznawczy służy do interpretacji chaotycznej impulsacji z pnia mózgu oraz napięć w ciele. Dzięki temu w snach wyraźniej widać, jakie konkretnie błędy poznawcze najbardziej doskwierają osobie i leżą u podłoża jej problemów, oraz które z nich powodują nastroju po wybudzeniu. Doweiko uważa, że samopoczucie jest determinowane przez marzenia senne (Doweiko 2004).

Ze względu na łatwość operacjonalizacji teorii poznawczych oraz ich mocne ugruntowanie w koncepcjach naukowych na podstawie rozważań Doweiki i Becka przeprowadziłem badanie nad wyczytywaniem przekonań osób śniących. Jego wyniki sugerują, że zabieg ten może być skuteczny (por. Dąbrowski 2015). Wynika z tego, że poznawczy paradygmat interpretacji snów oferuje korzyści zarówno pragmatyczne (pomoc w psychoterapii), jak i teoretyczne (łatwe w operacjonalizacji i mierzeniu wskaźniki), co za tym idzie - pozwala na zbliżenie się do istoty marzenia sennego. Temat wymaga dalszych badań, do których - mam nadzieję - niniejszy artykuł zachęci czytelników.

\section{Literatura:}

Beck A.T., 2004, Cognitive Patterns in Dreams and Daydreams [w:] Cognitive Therapy and Dreams, eds. R.I. Rosner, W.J. Lyddon, A. Freeman, New York: Springer Publishing Company.

Borbély A., 1990, Tajemnice snu, tłum. W., M. Szelenbergowie, Warszawa: PWN. Ciarkowska W., 2015, Sen w normie i patologii - cykl wykładów, nieopublikowane. 
Dąbrowski J., 2015, Czy można wyczytać przekonania z marzenia sennego?, praca magisterska pisana pod nadzorem M. Dragan.

Doweiko H.E., 1982, Neurobiology and Dream Theory: A Rapprochement Model, „Individual Psychology: Journal of Adlerian Theory, Research \& Practice" Vol. 38, No. 1.

Doweiko H.E., 2004, Dreams as an Unappreciated Therapeutic Avenue for Cognitive-Behavioral Therapists [w:] Cognitive Therapy and Dreams, eds. R.I. Rosner, W.J. Lyddon, A. Freeman, New York: Springer Publishing Company.

Drat-Ruszczak K., 2000, Teorie osobowości - podejście psychodynamiczne i humanistyczne [w:] Psychologia - podręcznik akademicki, t. 2, red. J. Strelau, Gdańsk: GWP.

Drozdowski P., Kokoszka A., 1993, Podstawowe pojęcia psychoanalizy [w:] Wprowadzenie do psychoterapii, red. A. Kokoszka, P. Drozdowski, Kraków: Akademia Medyczna im. Mikołaja Kopernika.

Dudek Z.W., 2007, Jungowska psychologia marzeń sennych: teoria, praktyka, interpretacje, Warszawa: Eneteia.

Freud S., 1952, On dreams, trans. J. Strachey, New York: Norton.

Freud S., 2004, Wstęp do psychoanalizy, tłum. S. Kempnerówna, W. Zaniewicki Warszawa: De Agostini Polska.

Hall C.S., Lindzey G., Campbell J.B, 2010, Teorie osobowości, tłum. J. Kowalczewska, J. Radzicki, M. Zagrodzki, Warszawa: PWN.

Hobson J.A., McCarley R.W., 1977, The Brain as a Dream State Generator: An Activation-Synthesis Hypothesis of the Dream Process, "The American Journal of Psychiatry” Vol. 134, Iss. 12.

Jung C.G., 1981, Archetypy i symbole: pisma wybrane, tłum. J. Prokopiuk, Warszawa: Czytelnik. Jung C.G., 1995, Podstawy psychologii analitycznej: Wykłady tavistockie, tłum. J. Prokopiuk, Warszawa: Wrota.

Jung C.G., 1999, Psychologia a alchemia, tłum. J. Prokopiuk, Warszawa: Wrota.

Kokoszka A., 1993, Podstawowe pojęcia psychoanalitycznej psychoterapii [w:] Wprowadzenie do psychoterapii, red. A. Kokoszka, P. Drozdowski, Kraków: Akademia Medyczna im. Mikołaja Kopernika.

Lombardi D.N., Elcock L.E., 1997, Freud versus Adler on dreams, "American Psychologist" Vol. 52, Iss. 5.

Padesky C.A., Greenberger D., 2004, Umyst ponad nastrojem: zmień nastrój poprzez zmianę sposobu myślenia, tłum. M. Słota, Kraków: Wydawnictwo Uniwersytetu Jagiellońskiego.

Rosner R.I., Aaron T., 2004, Beck's Dream Theory in Context: An Introduction to His 1971 Article on Cognitive Patterns in Dreams and Daydreams [w:] Cognitive Therapy and Dreams, eds. R.I. Rosner, W.J. Lyddon, A. Freeman, New York: Springer Publishing Company.

Vedfelt O., 1998, Wymiary snów: istota, funkcje i znaczenie marzeń sennych, tłum P. Billig, Warszawa: Eneteia.

Wojciszke B., 2012, Psychologia Społeczna, Warszawa: Scholar.

Zimbardo P.G., 1999, Psychologia i życie, tłum. E. Czerniawska et al., Warszawa: PWN.

Zimbardo P.G., Johnson R.L., McCann V., 2012, Jakie cykle występują w świadomości na co dzień? [w:] P.G. Zimbardo, R.L. Johnson, V. McCann, Psychologia: kluczowe koncepcje, t. 3: Struktura i funkcje świadomości, tłum. M. Guzowska-Dąbrowska, E. Czerniawska, A. Gruszka, Warszawa: PWN.

\section{Abstrakt}

Świat snu oraz świat wyobraźni to dwie bardzo zbliżone domeny. W artykule zadano pytanie o to, czy na podstawie marzeń sennych można wnioskować o rzeczywistych właściwościach psychicznych osób śniących. 
Omówiono teorie snu klasycznej psychoanalizy, psychologii analitycznej Carla Gustava Junga, psychologii indywidualnej Alfreda Adlera oraz teorie poznawcze Aarona Becka i Harolda Doweiki. Prezentację wymienionych badaczy wsparto danymi z neuropsychologii oraz chronobiologii.

\section{Słowa kluczowe}

marzenie senne, sen, psychoterapia, psychologia

\section{Summary}

Dream Based Psyche Diagnosis

Domain of dream and domain of imagination are close to each other. In this article it is discussed if there is a possibility to infer real psychological traits based on dreams.

Following dream theories are introduced: classical psychoanalytical theory, Carl Jung's analytical psychology, Alfred Adler's individual psychology and cognitive theories of Aaron Beck and of Harold Doweiko. Presentation of those items is supported by neuropsychological and chronobiological data.

\section{Keywords}

dream, sleep, psychotherapy, psychology 